\title{
Soil carbon and nitrogen regulation using organic and inorganic fertilizers for leaf physiological activity, grain yield and nutritional quality improvements in rice
}

\author{
Anas Iqbal \\ Guangxi University \\ Liang He \\ Guangxi University \\ Pengli Yuan \\ Guangxi University \\ Izhar Ali \\ Guangxi University
}

\section{Ahmad Khan}

The University of Agriculture Peshawar, Pakistan

Quan Zhao

Muhammad Zeeshan

Guangxi University

\section{Shakeel Ahmad}

Guangxi University

Ihsan Muhammad

Guangxi University

Muhammad Adnan

Saif Ullah

Shangqin Wei

Guangxi University

Fengwei Cheng

Guangxi University

Ligeng Jiang ( $\sim$ jiang@gxu.edu.cn )

Guangxi University

\section{Research Article}

Keywords: Soil, rice, carbon, starch, amylose, leaf photosynthetic rate 
Posted Date: October 12th, 2021

DOl: https://doi.org/10.21203/rs.3.rs-965000/v1

License: (c) (i) This work is licensed under a Creative Commons Attribution 4.0 International License. Read Full License 


\section{Abstract}

Organic fertilizers are widely used in agriculture production and change the soil carbon (C) and nitrogen (N) contents, thus improving crop production. The increased amount of soil $\mathrm{C}$ and $\mathrm{N}$ exhibit a greater potential to improve the leaf physiological activity, yields and grain quality of rice by improving soil fertility indices. To understand the relationship between soil $\mathrm{C}$ and $\mathrm{N}$ contents with leaf physiological activity and grain quality; organic fertilizers (i.e., cattle manure (CM) and poultry manure (PM)) coupled with chemical fertilizer (CF) was applied at the different proportion. The recommended rate of $\mathrm{N} 150$ ( $\mathrm{kg}$ $\mathrm{ha}^{-1}$ ) was provided from manure and $\mathrm{CF}$ using six treatments, i.e., $\mathrm{T}_{1}-\mathrm{CF}_{0} ; \mathrm{T}_{2}-100 \% \mathrm{CF} ; \mathrm{T}_{3}-60 \% \mathrm{CM}+$ $40 \% \mathrm{CF} ; \mathrm{T}_{4}-30 \% \mathrm{CM}+70 \% \mathrm{CF} ; \mathrm{T}_{5}-60 \% \mathrm{PM}+40 \% \mathrm{CF}$, and $\mathrm{T}_{6}-30 \% \mathrm{PM}+70 \% \mathrm{CF}$. Results showed that soil organic $\mathrm{C}(\mathrm{SOC})$, total $\mathrm{N}(\mathrm{TN})$, leaf net photosynthetic rate $(P n)$, SPAD values, grain yield and grain quality attributes were significantly increased with combined organic and inorganic fertilizer application. Averaged over the years, $\mathrm{T}_{6}$ treatment significantly improved SOC, TN, $P n$, starch content (SC), amylose content (AC), and grain yield by $16 \%, 12 \%, 9 \%, 7 \%, 12 \%$, and $24 \%$, respectively, compared to CF-only. However, no significant differences among $T_{4}$ and $T_{6}$ were observed for studied parameters. In addition, the linear regression exhibited that $\operatorname{SOC}\left(R^{2}=0.70 * \star \& R^{2}=0.50 *\right)$ and $T N\left(R^{2}=0.62 * \& R^{2}=0.58^{\star}\right)$ were positively correlated with grain $S C$ and $A C$, respectively. Likewise, $P n\left(R^{2}=0.51 * \& R^{2}=0.62 *\right)$ were also positively associated with $S C$ and $A C$, respectively. The correlation analysis showed that improving SOC and TN played a key role in enhancing leaf physiological activity and grain nutritional quality. Thus, the combination of organic and inorganic fertilizers at a 30:70 ratio is a promising option for the improvement of soil fertility and grain yield of rice as well as grain nutritional traits.

\section{Introduction}

Improving crop production and quality to feed the global rising population and sustain high living standards has become a great challenge, recently (Fischer et al., 2014). After green revaluation, the modern farming system had played a crucial role in feeding the world's population (Jensen et al., 2011) but relied on the usage of heavy chemical fertilizers (CF) (Chen et al., 2014; Zhang et al., 2016). However, the usage of $\mathrm{CF}$ had led to a significant decrease in soil quality and is a major concern for sustainable agricultural productivity and crop quality (Sarma et al., 2017; Agegnehu et al., 2014). In addition, the extreme $\mathrm{N}$ application causes significant environmental problems, such as increased greenhouse gas emission, soil acidification, and groundwater pollution (Mahajan et al., 2008; Cai et al., 2018). Application of $\mathrm{N}$ fertilizer for a long time has also decreased soil microbial diversity, and make compaction of arable soils, thereby suppressed plant growth and crop production (Guo et al., 2017; Yue et al., 2015). In China, it has been documented that the CF application rates are usually far higher than the crop requirements (Ju et al., 2009). It is perceived by the farmers treat CFs are the most reliable and effective way to improve crop production and their revenue (Yan et al., 2013; Qiao et al., 2012), but have totally ignored the ill effects on soil and environment by using the $\mathrm{N}$ fertilizers continuously. For example, in winter wheat and summer maize rotation, the annual fertilization of mineral $\mathrm{N}\left(550-600 \mathrm{~kg} \mathrm{~N} \mathrm{ha}^{-1}\right)$ was almost three times greater than the minimum fertilization rate i.e., about $180 \mathrm{~kg} \mathrm{~N} \mathrm{ha}^{-1}$ (Zhao et al., 2006; Cui et al., 2008). 
Consequently, a huge amount of the applied nutrients, particularly $\mathrm{N}$ lost to the environment and have negative effects.

Organic fertilizers, such as farmyard manure (FYM), green manure, straw and compost are an alternative source of fertilizers that can provide various benefits over CF, such as improved soil health (Thangarajan et al., 2013), increased soil fertility (lqbal et al., 2019a; Ali et al., 2020a), maintain soil quality and health (Xie et al., 2014; Ali et al., 2020b), and in particular, similar or even greater crop grain yields in some cases (Iqbal et al., 2020b; Seufert et al., 2012). Moreover, organic manure fertilization could provide all essential nutrients required for plant growth and is also considered eco-friendly (Ullah 2020; Gu et al., 2015). But organic manure is quite low in nutrients content and its releasing capability is also low to meet plant demands in a short time, therefore the sole fertilization of manure cannot meet the usual demands of plants nutrients. Therefore, the organic fertilizers if coupled with mineral fertilizer, can be considered a better approach to enhance soil quality on a sustainable base and crop productivity than sole CF application (Kumar et al., 2017; Bandyopadhyay et al., 2010). However, gaps still exist in the knowledge presently available about the responses of soil chemical properties and leaf physiological traits with grain quality attributes and grain yield of rice using the various proportion of organic and inorganic $\mathrm{N}$ fertilization.

Rice is one of the major stable crops in China with a per capita consumption of 100 to $120 \mathrm{~kg} \mathrm{year}^{-1}$, which is almost 2.2 times the world average (FAO, 2016; Ding and Zhai, 2013). Rice grain quality determination can judge by four components, i.e., appearance, cooking, milling and nutritional quality ( $\mathrm{Li}$ et al., 2003; Stockdale et al., 2001). Environmental factors, such as temperature, precipitation, ecological zone, and amount and type of fertilization significantly affecting rice grain quality traits (Iqbal et al., 2020; Patindol et al., 2015). Most importantly, the accumulation of starch content in the grain is closely related to the rate and timing of $\mathrm{N}$ fertilization which can be improved by using the optimum rate of $\mathrm{N}$ (Yang et al., 2020; Zhou et al., 2020). In a conventional agricultural system, the excessive use of $\mathrm{N}$ is not suitable for the accumulation of grain starch and therefore does not result in high-quality rice grains (Guo et al., 2017). This may be due to the starch mobilizing enzyme activities, which is severally affected by $N$ fertilization (Tang et al., 2019; Iqbal et al., 2020). Moreover, earlier findings have also shown that rice grain filling rate (starch accumulation) is strongly associated with the rice grain processing and appearance qualities (Shen et al., 1997; Jin et al., 2000; Sun and Yang, 2008). However, we do not yet have full knowledge of the mechanism for linking soil properties to grain quality characteristics under the joint application of manure and mineral $\mathrm{N}$ fertilizers. Therefore, in conventional farming systems, improving the quality of grain is very important by adjusting the proportion of organic and inorganic fertilizer.

It is well documented that fertilization improves the grain yield, however, most of the studies were conducted on a weight basis of organic fertilizers rather than the specific rate and $\mathrm{N}$ concentration along with mineral $\mathrm{N}$ fertilizer (Zhang et al., 2015; Arif et al., 2015). Therefore, the primary mechanism of $\mathrm{N}$ on a concentration basis remains unknown. Moreover, there is a lack of information on the role and relationship of soil chemical and leaf physiological characteristics to the quality and yield of rice. So, it 
was expected from the present study that organic $\mathrm{N}$ along with synthetic $\mathrm{N}$ fertilization could improve soil health, which in turn will have a significant role in higher leaf physiological activity, rice yield and grain qualitative traits. The aims of this experiment are: (1) to explore the combined effect of organic and inorganic $\mathrm{N}$ on soil quality; (2) to evaluate the integrated effect of organic and mineral fertilizers on leaf physiological activity, rice yields and grain qualitative traits; (3) To examine the relationship among soil quality, leaf physiological activity and grain nutritional quality.

\section{Materials And Methods 2.1 Site description}

Field experiment at the research farm of Guangxi University, China was conducted in 2019 and 2020 during early season runs (from March-July) and the late season (from July-November). This site experiences a subtropical monsoon climate, with a total annual rainfall of $1398 \mathrm{~mm}$, and an average annual temperature of $24.8^{\circ} \mathrm{C}$ (Figure 1). The soil is classified as Ultisols (USDA soil classification), which is slightly acidic with a pH of 5.96. The soil physico-chemical properties indicated that the soil contained $18.75 \mathrm{~g} \mathrm{~kg}^{-1} \mathrm{SOC}$ and $1.64 \mathrm{~g} \mathrm{~kg}^{-1}$ total nitrogen (TN), with other details shown in Table 1. 
Table 1

Physical and chemical properties of soil and manure before the experimentation.

\begin{tabular}{|c|c|c|c|}
\hline \multirow[t]{2}{*}{ Properties } & \multicolumn{2}{|r|}{ Cattle } & \multirow{2}{*}{$\begin{array}{l}\text { Poultry } \\
\text { Manure }\end{array}$} \\
\hline & Soil & Manure & \\
\hline Porosity (\%) & 40.52 & - & - \\
\hline Moisture content (\%) & 11.93 & - & - \\
\hline Bulk density $\left(\mathrm{g} \mathrm{cm}^{-3}\right)$ & 1.36 & 0.81 & 0.74 \\
\hline pH (water) & 5.94 & 7.75 & 7.95 \\
\hline $\operatorname{SOC}\left(\mathrm{g} \mathrm{kg}^{-1}\right)$ & 14.56 & 146.33 & 164.22 \\
\hline $\operatorname{SOM}\left(\mathrm{g} \mathrm{kg}^{-1}\right)$ & 25.08 & 254.63 & 282.42 \\
\hline Total N ( $\left.\mathrm{g} \mathrm{kg}^{-1}\right)$ & 1.41 & 9.76 & 13.58 \\
\hline Total P $\left(\mathrm{g} \mathrm{kg}^{-1}\right)$ & 0.75 & 10.12 & 7.32 \\
\hline Total K $\left(\mathrm{g} \mathrm{kg}^{-1}\right)$ & - & 14.22 & 9.76 \\
\hline Available $\mathrm{N}\left(\mathrm{mg} \mathrm{kg}^{-1}\right)$ & 134.7 & - & - \\
\hline Available P $\left(\mathrm{mg} \mathrm{kg}^{-1}\right)$ & 23.12 & - & - \\
\hline Available $\mathrm{K}\left(\mathrm{mg} \mathrm{kg}^{-1}\right)$ & 233.3 & - & - \\
\hline C:N ratio & 7.16 & 14.92 & 12.98 \\
\hline $\begin{array}{l}\text { Note: SOC-soil organi } \\
\text { potassium, C: } \mathrm{N} \text {-carbo }\end{array}$ & anic $m$ & trogen, $\mathrm{P}$ & ous, K- \\
\hline
\end{tabular}

The double rice season experiment was arranged in a randomized complete block design having three replications. The plot size was $3.9 \mathrm{~m} \times 6 \mathrm{~m}\left(23.4 \mathrm{~m}^{2}\right)$. Organic fertilizers at the recommended rate of $\mathrm{N}$ $\left(150 \mathrm{~kg} \mathrm{ha}^{-1}\right)$ i.e., poultry manure (PM), cattle manure (CM), and chemical fertilizer (CM) as urea was used in this study in six different proportions: $\mathrm{T}_{1}-\mathrm{CF}_{0} ; \mathrm{T}_{2}-100 \% \mathrm{CF} ; \mathrm{T}_{3}-60 \% \mathrm{CM}+40 \% \mathrm{CF} ; \mathrm{T}_{4}-30 \% \mathrm{CM}+$ $70 \% \mathrm{CF} ; \mathrm{T}_{5}-60 \% \mathrm{PM}+40 \% \mathrm{CF}$, and $\mathrm{T}_{6}-30 \% \mathrm{PM}+70 \% \mathrm{CF}$ used.

The rice seeds were germinated in plastic trays, and the uniform-sized 25 days old seedlings were transferred into the rice field. The nutrient contents of organic fertilizers and the quantity of all treatments are shown in Table 2. The $\mathrm{N}$ and $\mathrm{K}$ fertilizers were applied in three splits: $50 \%$ initially before transplanting, $30 \%$ at tillering, and $20 \%$ at the heading stage. All phosphate fertilizer was applied before transplanting as a basal dose. Flooding was maintained from transplantation to physiological maturity. 
During the entire rice growth period, standard agronomic practices, including irrigation and pesticide application was performed the same for all amendments.

Table 2

Nutrient contents and amount of nutrients provided to each plot and application time.

\begin{tabular}{|c|c|c|c|c|c|c|}
\hline Treatment & $\begin{array}{l}\text { N } \\
(\mathrm{g} \\
\left.\text { plot }^{-1}\right)\end{array}$ & $\begin{array}{l}\text { Urea } \\
\left(\text { gplot }^{-1}\right)\end{array}$ & $\begin{array}{l}\text { CM, } \\
\text { PM, } \\
\left(\text { kgplot }^{-1}\right)\end{array}$ & $\begin{array}{l}\text { Basal } \\
\text { fertilization } \\
\left(\mathrm{kg} \mathrm{plot}^{-1}\right)\end{array}$ & $\begin{array}{l}\text { Tillering } \\
(\mathrm{g} \\
\text { plot }^{-1} \text { ) }\end{array}$ & $\begin{array}{l}\begin{array}{l}\text { Panicle } \\
\text { initiation }\end{array} \\
\left(\mathrm{g} \mathrm{plot}^{-1}\right)\end{array}$ \\
\hline $\mathrm{T}_{1}: \mathrm{CF}_{0}$ & 0 & 0 & 0 & $\begin{array}{l}\mathrm{P}_{2} \mathrm{O}_{2}: 0.93, \mathrm{KCl}: \\
0.30\end{array}$ & $\begin{array}{l}\mathrm{KCl}: \\
0.30\end{array}$ & Urea: 0 \\
\hline $\mathrm{T}_{2}: 100 \% \mathrm{CF}$ & 351 & 753 & 0 & $\begin{array}{l}\text { Urea: } 0.45 \text {, } \\
\mathrm{P}_{2} \mathrm{O}_{2}: 0.93, \mathrm{KCl}: \\
0.30\end{array}$ & $\begin{array}{l}\text { Urea: } \\
150, \\
\text { KCl: } \\
0.30\end{array}$ & Urea: 150 \\
\hline $\begin{array}{l}\mathrm{T}_{3}: 60 \% \mathrm{CM}+40 \% \\
\mathrm{CF}\end{array}$ & 351 & 301 & 21.5 & $\begin{array}{l}\text { Urea: } 0, \mathrm{CM}: \\
21.5 \text {, } \\
\mathrm{P}_{2} \mathrm{O}_{2}: 0.93, \mathrm{KCl}: \\
0.30\end{array}$ & $\begin{array}{l}\text { Urea: } \\
150, \\
\\
\text { KCl: } \\
0.30\end{array}$ & Urea: 150 \\
\hline $\begin{array}{l}\mathrm{T}_{4}: 30 \% \mathrm{CM}+70 \% \\
\mathrm{CF}\end{array}$ & 351 & 527 & 10.7 & $\begin{array}{l}\text { Urea:1.17, CM: } \\
\text { 10.7, } \\
\mathrm{P}_{2} \mathrm{O}_{2}: 0.93, \mathrm{KCl} \text { : } \\
0.30\end{array}$ & $\begin{array}{l}\text { Urea: } \\
150, \\
\text { KCl: } \\
0.30\end{array}$ & Urea: 150 \\
\hline $\begin{array}{l}T_{5}: 60 \% P M+40 \% \\
C F\end{array}$ & 351 & 301 & 15.5 & $\begin{array}{l}\text { Urea: 0, PM: } \\
\text { 15.5, } \\
\mathrm{P}_{2} \mathrm{O}_{2}: 0.93, \mathrm{KCl} \text { : } \\
0.30\end{array}$ & $\begin{array}{l}\text { Urea: } \\
150, \\
\\
\text { KCl: } \\
0.30\end{array}$ & Urea: 150 \\
\hline $\begin{array}{l}\mathrm{T}_{6}: 30 \% \mathrm{PM}+70 \% \\
\mathrm{CF}\end{array}$ & 351 & 527 & 7.7 & $\begin{array}{l}\text { Urea: } 1.17, \mathrm{PM} \text { : } \\
\text { 7.7, } \\
\mathrm{P}_{2} \mathrm{O}_{2}: 0.93, \mathrm{KCl} \text { : } \\
0.30\end{array}$ & $\begin{array}{l}\text { Urea: } \\
150, \\
\\
\text { KCl: } \\
0.30\end{array}$ & Urea: 150 \\
\hline
\end{tabular}

Note: $\mathrm{N}$-nitrogen, $\mathrm{CK}$-control, $\mathrm{CF}$-chemical fertilizer (urea), $\mathrm{CM}$-cattle manure, $\mathrm{PM}$-poultry manure, $\mathrm{P}_{2} \mathrm{O}_{2}$-superphosphate, $\mathrm{KCl}$-potassium chloride.

\subsection{Soil sampling and measurement \\ 2.3.1 Soil properties}

Samples were obtained by a core sampler at a depth $(0-20 \mathrm{~cm})$ from each treatment immediately after the late-season rice harvest in 2019-2020. Soil sampling was done at five different points and then mix 
to make a composite sample, and divide into two parts, one part was used for the measurements of soil nutrients, and the other was stored at $4{ }^{\circ} \mathrm{C}$ for molecular analysis.

Soil organic $\mathrm{C}$ was determined by the $\mathrm{K}_{2} \mathrm{Cr}_{2} \mathrm{O}_{7}-\mathrm{H}_{2} \mathrm{SO}_{4}$ oxidation method (Wang et al., 2003). For soil TN analysis, $200 \mathrm{mg}$ of the samples were processed using the salicylic acid-sulfuric acid-hydrogen peroxide method (Ohyama et al. 1991), and total $\mathrm{N}$ was measured using the micro-Kjeldahl technique according to Jackson (1956).

\subsubsection{Leaf physiological traits}

The $P n$ and SPAD value was found at tillering, heading and ripening stage during both years. From every plot, fully expanded flag leaves were targeted for $P n$ and SPAD value assessment. Portable photosynthesis (Li-6400, Li-COR Inc., Lincoln, NE, USA) system was used for Pn measurement on a shiny day: air humidity $(70 \%)$, light intensity $\left(1200 \mu \mathrm{mol} \mathrm{m}^{-2} \mathrm{~s}^{-1}\right), \mathrm{CO}_{2}\left(375 \mu \mathrm{mol} \mathrm{mol}^{-1}\right)$, and temperature $\left(28^{\circ} \mathrm{C}\right)$. A SPAD meter (SPAD-502, Minta Camera Co., Osaka, Japan) was used to take SPAD values of the 4 uppermost leaves on each plant at tillering, heading and ripening stage.

\subsubsection{Rice grain yield, grain nutritional and noodles appearance traits}

Rice plants from the whole plot area were harvested at maturity to measure the grain yield of rice and accommodated to $14 \%$ moisture content. For AC and SC concentration, rice grains were ground using a mortar, and the powder was then degreased two times with anhydrous ether. The total grain SC and AC were determined via the dual-wavelength iodine binding method as suggested by $\mathrm{He}$ (1985) and Zhu et al. (2008). Grain crude protein content was measured as the product of grain N contents and 5.75 (protein conversion coefficient) according to Fujihara et al. (2008). The value of dissolved starch was measured according to the method of Weiguo et al. (2005). The noodles expansion rate and evenness were determined according to the procedure as suggested by Shaomao and Mao, (2004) and Guo et al. (2016), respectively.

\subsubsection{Statistical analysis}

The collected data on soil chemical traits, leaf physiology, yield, and grain qualitative attributes were analyzed according to the ANOVA techniques relevant to RCB design using Statistics 8.1 software. The data were first checked for a normal test. Furthermore, data in percentage were arcsine transformed to normalize the variables before analysis. The analysis was performed combined over the years, to detect changes between years as well as in fertilizer treatments. Fertilizer treatments were considered as a fixed factor, years were considered as a repetitive measured factor and also a fixed effect. Likewise, the interaction among fertilizer treatments and the years was taken as a fixed effect. But, the interaction of years and treatment with replications was taken as a random effect. The means were separated using Tukey's test at $p<0.05$. Linear regression analysis was performed to evaluate the relationship of SOC, TN, $P n$, and SPAD value with grain SC and AC. 


\section{Results}

\subsection{Soil Chemical properties}

The effects of combined organic and inorganic $\mathrm{N}$ fertilization treatments on soil chemical attributes are shown in Figure 2. The co-applied fertilizers significantly increased SOC and soil organic matter (SOM) during both years. In both years, the SOC and SOM content were maximum in $\mathrm{T}_{3}$ and $\mathrm{T}_{5}$ treatments than in the rest of the treatments. Furthermore, the SOC and SOM contents among the different treatments showed the same pattern across years, and average increases in SOC and SOM content were $29.3 \%$ and $29.3 \%$ in the $T_{3}$ treatment, respectively, compared with control $\left(T_{2}\right)$. But, $T_{5}$ was non-significant $(P<0.05)$ with $T_{3}$. Compared with control, the combined treatments, such as $T_{4}$ and $T_{6}$ showed significantly higher SOC and SOM content. Moreover, substantial enhancements were detected in SOC and SOM content during the second year. The average increase in SOC content in the year 2020 was $27.2 \%$ compared with the year 2019.

The difference in soil TN and available N (AN) content at the $0-20 \mathrm{~cm}$ soil depth is shown in Figure 3 . Soil TN and AN contents were considerably improved in the combined treatments compared with CT in both years. The average increases in $\mathrm{TN}$ and $\mathrm{AN}$ were $24.2 \%$, and $17.02 \%$, respectively, in the $\mathrm{T}_{3}$ treatment compared with control. But, $T_{5}$ was similar $(P<0.05)$ non-significant with $T_{3}$. Likewise, the integrated treatments like $\mathrm{T}_{4}$ and $\mathrm{T}_{6}$ had considerably higher soil $\mathrm{TN}$ and $\mathrm{AN}$ contents compared to control. Furthermore, significant improvements were observed in TN and AN contents during the seceding year. The average increment in TN and AN contents in the year 2020 was $9.55 \%$ and $12.28 \%$, respectively, which was higher than the year 2019.

\subsection{Soil Leaf physiological traits}

Leaf photosynthetic rate $(P n)$ and SPAD values at the tillering, heading, and ripening stage was significantly affected by $\mathrm{N}$ amendments during the year 2019 and 2020 (Fig. 4 \& 5). Both traits exhibited a quadratic trend across growth, with higher values at heading and lower values at the ripening stage in both years. Further, the $P n$ and SPAD values showed a similar trend across the years. Average across the years, at the tillering stage, the $P n$ and SPAD were $20 \%$ and $23 \%$, respectively, higher in $\mathrm{T}_{2}$ compared to $\mathrm{T}_{1}$, while at the heading and ripening stage, $P n$ and SPAD were significantly higher in $T_{6}$ and $T_{4}$ compared with other treatments. Average increases across the growth stages and years in Pn and SPAD were 16\% and $18 \%$, respectively, in $\mathrm{T}_{6}$ treatment compared to $\mathrm{T}_{1}$. Furthermore, the joint $\mathrm{N}$ treatments, such as $\mathrm{T}_{3}$ and $\mathrm{T}_{5}$ also improved leaf $P n$ and SPAD values.

\subsection{Rice grain nutritional and appearance qualities}

Grain nutritive quality is a primary feature of rice, such as starch, amylose and protein content. The collective use of organic and mineral fertilizers had significantly improved rice grain SC, AC and PC in 
both years 2019 and 2020 (Table 3). The integrated treatment i.e., T 6 significantly enhanced the SC, AC and $P C$ by $6.4 \%, 12.7 \%$ and $12.2 \%$, respectively, compared to $T_{2}$. But, the treatment $T_{4}$ and $T_{6}$ were statistically $(P<0.05)$ non-significantly different from each other. Similarly, the co-applied organic and synthetic $\mathrm{N}$ treatments i.e., $\mathrm{T}_{3}$ and $\mathrm{T}_{5}$ also significantly increased the nutritive traits of grain compared to sole urea. The lowest content of SC, AC and PC were noted in control plots during both years.

The influence of joint manure and synthetic $\mathrm{N}$ fertilizer application on rice noodle appearance traits are presented in Table 3. The combined fertilization had no significant effects on starch dissolving value, noodles expansion rate and evenness.

\subsection{Rice grain yield}

The combined organic-inorganic fertilizer application significantly affected the grain yield of rice in both 2019 and 2020 (Table 3). Compared with control $\left(\mathrm{T}_{2}\right)$, the co-applied $\mathrm{N}$ fertilization considerably improved the grain yield of rice across years. The grain yield of the $T_{6}$ treatment was enhanced by $15 \%$ and $33 \%$ during 2019 and 2020, respectively, relative to control. However, there were no significant $(P<$ $0.05)$ differences in grain yield among the $T_{4}$ and $T_{6}$ treatments. Similarly, the combined treatments, such as $T_{5}$ and $T_{3}$ also significantly increased grain yield, compared to control. Significant improvements in grain yield were observed among the different years, and the average grain yield was increased by $14 \%$ in 2020 compared to 2019.

\subsection{Relationship of the soil chemical traits with grain starch and amylose contents}

Rice grain starch and amylose content were strongly reliant on soil parameters. This was confirmed by linear regression analysis, which showed that the grain SC was positively correlated with SOC content $\left(R^{2}=0.70^{\star *}\right.$ Fig. $\left.6[A]\right)$ and TN $\left(R^{2}=0.62^{*}\right.$ Fig. $\left.6[C]\right)$. Similarly, the AC showed a positive relationship with $\operatorname{SOC}\left(R^{2}=0.52 *\right.$ Fig. $\left.6[B]\right)$ and TN $\left(R^{2}=0.58^{*}\right.$ Fig. $\left.6[D]\right)$. The leaf physiological traits, such as $P n$ and SPAD values were correlated with $\mathrm{SC}$ and $\mathrm{AC}$. The positive correlation was observed of $\mathrm{SC}$ with $P n\left(\mathrm{R}^{2}=0.51^{*}\right.$ Fig. $7[A])$ and SPAD ( ${ }^{2}=0.60 *$ Fig. $\left.7[C]\right)$; as well as of $A C$ and $S C$ with $P n\left(R^{2}=0.62^{\star}\right.$ Fig. 7 [B]) and SPAD $\left(R^{2}=0.63^{\star}\right.$ Fig. 7 [D]). Such results showed that the improvements in soil SOC, $T N$ and leaf physiological activity directly affect the starch and amylose accumulation in rice grain.

\section{Discussion}

The present agricultural system is massively dependent on CFs, which have adversely affected soil quality, environment and cereal yields as well as grains quality. The improvement of soil fertility and cereal yields and its quality on a sustainable basis is novel research these days (Adekiya et al., 2019; Iqbal et al., 2019). Therefore, the influence of a cumulative application of manure and mineral fertilizers on soil chemical properties. Leaf physiological traits, grain yield and its qualitative traits of rice were 
undertaken in field studies to devise a sound strategy for improvement in these indicators on a sustainable basis.

\subsection{Soil quality}

The collective use of organic and inorganic $\mathrm{N}$ significantly increased the SOC, SOM, TN and AN concentration in the soil as compared with sole urea application (Fig. $2 \& 3$ ). The decomposition of organic fertilizer slowly released nutrients to the soil and exhibited that rising the organic fertilizer ratio from $30-60 \%$ had enhanced the soil health. Soil organic $C$ is a vital indicator of soil health and fertility (Stockmann et al., 2013; Johanne's et al., 2017), soil having greater SOC would have better health. A significant improvement in SOC content was noted under combined treatments compared with control (Fig. 2). The enhancement in SOC and SOM could be explained by two possible mechanisms, i.e., the direct addition of $\mathrm{C}$ by adding organic fertilizer and improvement in rhizosphere quality by increased root exudate as a result of improved plant root activities (Bitew and Alemayehu, 2017). In fact, the SOC at any certain position strongly relies on the annual organic turnover (i.e., plant root exudates, root and shoot stubbles, and their recycling) (Adekiya et al., 2019; Biratu et al., 2019). In accordance with our finding, Purakayastha et al., (2008), documented that manure significantly improves soil $\mathrm{C}$ in the top layer.

The co-applied fertilization of manure and mineral fertilizers significantly improved the content of total and available N (Fig. 3). This is mainly due to the addition of organic fertilizer such as CM or PM, which had a positive effect on the soil $\mathrm{N}$ and other nutrients. This might be related to the direct addition of $\mathrm{N}$ when the organic fertilizer was added to the soil had increased the TN, but its decomposition had increased the AN (Wei et al., 2013). Another possible explanation for enhancements in soil nutrients might be related to the ability of organic fertilizers in reducing the leaching of nutrients and thus had a greater capability of absorbing these leachates. The greater absorbing capability is due to improvement in water holding capacity, a decline in nutrients leaching, and consequently greater availability of NPK (Adekiya et al., 2019; Murmu et al., 2013). Our results are also in line with Purakayastha et al. (2008), who concluded that organic manure coupled with mineral fertilizer improves soil organic $C$ by $11-80 \%$ and soil total $\mathrm{N}$ by $56-90 \%$ in the upper layer.

\subsection{Leaf physiological activity}

The chlorophyll content directly affects the plant photosynthetic activities (Wittmann et al., 2001), and hence crop production. Photosynthesis is the key driver of crop production by increasing plant growth and dry matter accumulation as well as displayed a strong response to N-uptake and water (Wittmann et al., 2001). Leaf $P n$ and SPAD values were noted higher under co-applied manure and mineral $\mathrm{N}$ fertilizers treatments compared with the sole synthetic $\mathrm{N}$ fertilization (Fig. 3). This increment might be due to improvement in soil health and fertility, declines in nutrients leaching downside (Geng et al., 2019) due to increased organic and inorganic fertilization. We confirmed that the combined manure and mineral $\mathrm{N}$ improved soil fertility (Fig. 2 \& 3), which eventually increased the root's ability to absorb more water and nutrients, lead to higher stomatal conductance and $\mathrm{CO}_{2}$ fixing (Iqbal et al. 2019). The higher Pn and SPAD values of the plant at heading and ripening stages under combined fertilization treatment could be due to 
faster release of nutrient from mineral fertilizers and slow and steady releases of the plant needed nutrient from manure upon decomposition (Iqbal et al., 2020; Ali et al., 2020).

\subsection{Rice grain yield}

The integrated use of manure and synthetic $\mathrm{N}$ significantly increased the grain yield of rice compared with that of sole synthetic fertilizer (Table 3). The improvements in grain yield could be owing to the enhanced soil fertility and functionality under mutual treatments, which ultimately increased crop growth, biomass and yield. Our findings are also in agreement with the results of Yang et al. (2008) and Akhtar et al. (2018) who reported that cereals grain yield is closely associated to soil properties and fertilization application. Similarly, Mangalassery et al. (2018) concluded that the continued application of organic manure coupled with mineral fertilizers improves the biomass and rice yield.

\subsection{Rice grain nutritional and appearance traits}

The concentration of SC and AC strongly affects the eating and cooking quality of rice noodles (AduKwarteng et al., 2003). The combined (organic fertilizer and CF) fertilization considerably improved the $\mathrm{AC}$ and PC of grain compared with sole CF fertilization (Table 3 ). The observed improvement in PC and $\mathrm{AC}$ under integrated amendments explores that both fertilizers deliver enough amount of nutrients (macro + micro), mainly N, which is essential for growth and development for rice. Kumar et al. (2007), finding are in agreements with our finding, and had reported that co-application of inorganic and organic fertilizers enhance grain quality and AC by $7 \%$ than sole inorganic fertilizer. Similarly, Sravan and Sing (2019) concluded that the higher grain protein content of rice was associated with the improvement of soil fertility. Moreover, the manure coupled mineral fertilizers did not significantly influence rice noodle physical traits, such as starch dissolving value, expansion rate, and evenness (Table 3 ). In general, rice grain and noodle physical quality do not indicate variability in the short-time intake under manure fertilization. However, the combined organic and inorganic amendment improves the physical quality of rice grain, which is also supported by earlier researchers (Kesarwani et al., 2016).

Soil quality and leaf physiological traits had affected the grain nutritional quality. The correlation analysis showed a strong relationship between soil properties and rice grain starch and amylose (Fig. 5 \& 6). Changes in soil supply $\mathrm{C}$ and $\mathrm{N}$ and the improvement in the potential and regulation of source-sinktranslocation might be the possible explanation for this shift, which had a positive impact on the grain filling process and grain quality (Wu et al., 2020). The leaf $P n$ and chlorophyll content showed a significant and positive relation with grain quality (Fig. 6). The higher leaf Pn and SPAD values were primarily due to the enhanced soil health under integrated organic and inorganic armaments (Fig. 2 \& 3 ), which eventually increased root growth, nutrients and water uptake. Such improvement had increased the leaf physiological activity. Moreover, the combined treatments prolonged $\mathrm{N}$ supply and leaf physiological activity during the ripening period; and thus, might have enhanced the accumulation capacity of the "source", and ultimately improved the grain filling process.

\section{Conclusion}


In this study, the combined application of manure and synthetic fertilizers significantly improved the soil fertility, leaf physiological activity, rice yield and grain quality attributes. Higher SOC, TN, Pn, AC and PC, as well as grain yield, were observed in the treatments as compared to sole urea application during both years. Improvements in leaf $P n, S P A D$ value, grain yield and grain nutritional characteristics were primarily due to enhanced soil quality under manure application. In addition, according to the linear regression analysis, the nutritional characteristics of rice grain are strongly dependent on soil fertility and leaf physiological activity. It is concluded that the combined application of manure and chemical fertilizers at 30:70 ratio is the best strategy for producing higher rice yields both quantitatively and qualitatively along with improvement in soil fertility.

\section{Abbreviations}

C

carbon

$\mathrm{CM}$

cattle manure

PM

poultry manure

CF

chemical fertilizer

SOC

soil organic carbon

SOM

soil organic matter

TN

total nitrogen

$P n$

net photosynthetic rate

SC

starch content

AC

amylose content

FYM

farm yard content

RCBD

randomized complete design.

\section{Declarations}

\section{Acknowledgments}


This study was funded by the National Key Research and Development Project of China (2016YFD030050902). We thank collaborators at Agriculture Station, Guangxi University for help to excuse this study.

Conflicts of Interest: The authors declare no conflicts of interest.

\section{References}

Adekiya AO, Agbede TM, Aboyeji CM, Dunsin O, Simeon VT (2019). Effects of biochar and poultry manure on soil characteristics and the yield of radish. Scientia horticulturae. 243, pp.457-463.

Adu-Kwarteng E, Ellis WO, Oduro I, Manful JT 2003. Rice grain quality: a comparison of local varieties with new varieties under study in Ghana. Food Control, 14(7), pp.507-514.

Agegnehu G, Lakew B, Nelson PN 2014. Cropping sequence and nitrogen fertilizer effects on the productivity and quality of malting barley and soil fertility in the Ethiopian highlands. Archives of Agronomy and Soil Science 60, 1261-1275.

Arif M, Tasneem M, Bashir F, Yaseen G, lqbal RMJJAR. Effect of integrated use of organic manures and inorganic fertilizers on yield and yield components of rice. J. Agric. Res 2014; 52(2):197-206.

Bandyopadhyay K, Misra A, Ghosh P, Hati KE ect of integrated use of farmyard manure and chemical fertilizers on soil physical properties and productivity of soybean. Soil Tillage Res 2010, 110, 115-125.

Beckles DM, Thitisaksakul M 2014. How environmental stress affects starch composition and functionality in cereal endosperm. Starch-Starke 66 (1-2), 58-71.

Biratu GK, Elias E, Ntawuruhunga P 2019. Soil fertility status of cassava fields treated by integrated application of manure and NPK fertilizer in Zambia. Environmental Systems Research, 8(1), pp.1-13.

Bitew Y, Alemayehu M 2017. Impact of crop production inputs on soil health: a review. Asian Journal Plant Science, 16(3), pp.109-131.

Cai A, Zhang W, Xu M, Wang B, Wen S, Shah SAAJNcia. Soil fertility and crop yield after manure addition to acidic soils in South China. Nutrient cycling in agroecosystems 2018;111(1):61-72.

Chen Z, Ding W, Luo Y, Yu H, Xu Y, Müller C, Xu X, Zhu T 2014. Nitrous oxide emissions from cultivated black soil: a case study in Northeast China and global estimates using empirical model. Global Biogeochemical Cycles 28, 1311-1326.

Consumer Econ. 29 (4), 18-23 (In Chinese).

Cui Z, Zhang F, Miao Y. Sun Q, Li F, Chen X, Li J, Ye Y, Yang Z, Zhang Q, Liu C 2008. Soil nitrate-N levels required for high yield maize production in the North China Plain. Nutrient Cycling in Agroecosystems, 
82(2), pp.187-196.

Daszkowska-Golec A, Szarejko I 2013. Open or close the gate-stomata action under the control of phytohormones in drought stress conditions. Frontiers in plant science, 4, p.138.

Ding Z, Zhai L 2013. Current status and forecast of rice consumption in Asian countries.

FAO Food and Agriculture Organization, 2016. FAO Statistics [OL].

Fischer RA, Byerlee D, Edmeades GL 2014. Crop yields and global food security: will yield increase continue to feed the world? Eur. Rev. Agric. Econ. 43, 191-192.

Fujihara S, Sasaki H, Aoyagi Y, Sugahara T 2008. Nitrogen-to-protein conversion factors for some cereal products in Japan. Journal of food science, 73(3), pp.C204-C209.

Geng Y, Cao G, Wang L, Wang S 2019. Effects of equal chemical fertilizer substitutions with organic manure on yield, dry matter, and nitrogen uptake of spring maize and soil nitrogen distribution. PloS one, 14(7), p.e0219512.

Gu B, Ju X, Chang J, Ge Y, Vitousek PM 2015 Integrated reactive nitrogen budgets and future trends in China. Proceedings of the National Academy of Sciences of the United States of America 112, 8792.

Guo J, Gao L, Xie K, Ling N, Shen Q, Guo S 2017. rice production practices of high yield and high nitrogen use efficiency in Jiangsu, China. Scientific Rep. 7 (1), 1-10.

Guo J, Hu X, Gao L, Xie K, Ling N, Shen Q, et al. The rice production practices of high yield and high nitrogen use efficiency in Jiangsu, China. Scientific reports. 2017;7(1):1-10.

Guo LL, Zhou XQ, Xiong N, et al., 2016. Research on Sensory Evaluation Methods for Pressed and Fresh Rice Noodles. Modern Food Science and Technology, 32(02):253-261.

He Z 1985. Grain Quality and Its Analysis Technology. Agriculture press, Beijing.

Iqbal A, He L, Ali I, Ullah S, Khan A, Khan A, Akhtar K, Wei S, Zhao Q, Zhang J, Jiang L 2020. Manure combined with chemical fertilizer increases rice productivity by improving soil health, post-anthesis biomass yield, and nitrogen metabolism. Plos one, 15(10), p.e0238934.

Iqbal A, He L, Khan A, Wei S, Akhtar K, Ali I, Ullah S, Munsif F, Zhao Q, Jiang L 2019. Organic manure coupled with inorganic fertilizer: An approach for the sustainable production of rice by improving soil properties and nitrogen use efficiency. Agronomy, 9(10), p.651.

Jackson ML 1956. Soil Chemical Analysis-Advanced Course; University of Wisconsin: Madison, WI, USA, $\mathrm{p}, 991$. 
Jin ZX, Qiu TQ, Sun YL, Cui CH 2000. Study on the nature of formation of rice quality characters comparative study on the accumulation dynamic of compounds in the endosperm of different quality Japonica rice in the filling course. J. Northeast Agric. Univ. 31 (2), 105-111 in Chinese with English abstract.

Ju XT, Xing GX, Chen XP, Zhang SL, Zhang LJ, Liu XJ, Cui ZL, Yin B, Christie P, Zhu ZL, Zhang FS 2009. Reducing environmental risk by improving $\mathrm{N}$ management in intensive Chinese agricultural systems. Proceedings of the National Academy of Sciences, 106(9), pp.3041-3046.

Kesarwani A, Chiang PY, Chen SS 2016. Rapid visco analyzer measurements of japonica rice cultivars to study interrelationship between pasting properties and farming system. International Journal of Agronomy, 2016.

Kumar U, Shahid DM, Tripathi R, Mohanty S, Kumar A, Bhattacharyya P, Lal B, Gautam P, Raja R, Panda $\mathrm{BB}$, et al. Variation of functional diversity of soil microbial community in sub-humid tropical rice-rice cropping system under long-term organic and inorganic fertilization. Ecol. Indic 2017, 73, 536-543.

Kumar U, Shahid M, Tripathi R, Mohanty S, Kumar A, Bhattacharyya P, Lal B, Gautam P, Raja R, Panda BB, Jambhulkar NN 2017. Variation of functional diversity of soil microbial community in sub-humid tropical rice-rice cropping system under long-term organic and inorganic fertilization. Ecological Indicators, 73, pp.536-543

Li R, Li M, Ashraf U, Liu S, Zhang J 2006. Yield Analysis of Early Indica Rice Zhenguiai 1 in South China. China Rice, 1, 17.

Ma G, Liu W, Li S, Zhang P, Wang C, Lu H, Kang G 2019. Determining the optimal N input to improve grain yield and quality in winter wheat with reduced apparent $\mathrm{N}$ loss in the North China Plain. Front. Plant Sci. $10,181$.

Mahajan A, Bhagat R, Gupta RJSJoA. Integrated nutrient management in sustainable rice-wheat cropping system for food security in India. AARC Journal of Agriculture 2008;6(2):29-32.

Mangalassery S, Kalaivanan D, Philip PS 2019. Effect of inorganic fertilisers and organic amendments on soil aggregation and biochemical characteristics in a weathered tropical soil. Soil and Tillage Research, 187, pp.144-151.

Murmu K, Swain DK, Ghosh BC 2013. Comparative assessment of conventional and organic nutrient management on crop growth and yield and soil fertility in tomato-sweet corn production system. Australian Journal of Crop Science, 7(11), pp.1617-1626.

Ohyama T, Ito M, Kobayashi K, Araki S, Yasuyoshi S, Sasaki O, Yamazaki T, Soyama K, Tanemura R, Mizuno $Y$ Analytical procedures of $\mathrm{N}, \mathrm{P}, \mathrm{K}$ contents in plant and manure materials using $\mathrm{H} 2 \mathrm{SO} 4-\mathrm{H} 2 \mathrm{O} 2$ Kjeldahl digestion method. Bull. Fac. Agric. Niigata Univ. 1991, 43, 110-120. 
Patindol JA, Siebenmorgen TJ, Wang YJ 2015. Impact of environmental factors on rice starch structure: a review. Starch-Stärke 67 (1-2), 42-54.

Purakayastha TJ, Huggins DR, Smith JL 2008. Carbon sequestration in native prairie, perennial grass, notill, and cultivated Palouse silt loam. Soil Science Society of America Journal, 72(2), pp.534-540.

Qiao J, Yang LZ, Yan TM, Xue F, Zhao D 2012. Nitrogen fertilizer reduction in rice production for two consecutive years in the Taihu Lake area. Agric. Ecosyst. Environ. 146, 103-112

Sarma B, Borkotoki B, Narzari R, Kataki R, Gogoi N 2017. Organic amendments: effect on carbon mineralization and crop productivity in acidic soil. Journal of Cleaner Production 152, 157-166.

Seufert V, Ramankutty N, Foley JA 2012. Comparing the yields of organic and conventional agriculture. Nature 485, 229-232.

Shaomao R, Mao GQ 2004. Study on Rice Cooking Properties. Cereal \& Feed Industry, (09):21-24

Shen B, Chen N, Li TG, Luo YK 1997. Effect of temperature on rice chalkiness formation and changes of materials in endosperm. Chinese Journal of Rice Science 11 (3), 183-186 in Chinese with English abstract.

Sun J, Yang Z, 2008. Studies on correlation of rice quality and enzyme activity in grain filling period. Chinese Agricultural Science Bulletin. 24 (7), 32-38 in Chinese with English abstract.

Tang She, Haixiang Z, Wenzhe L, Zhi D, Qinyang Z, Wenzhu C, Shaohua W, Yanfeng D 2019. Nitrogen fertilizer at heading stage effectively compensates for the deterioration of rice quality by affecting the starch-related properties under elevated temperatures. Food Chem. 277 (2019), 455-462.

Thangarajan R, Bolan NS, Tian G, Naidu R, Kunhikrishnan A 2013. Role of organic amendment application on greenhouse gas emission from soil. The Science of the Total Environment 465, 72.

Wang S, Tian H, Liu J, Pan S 2003. Pattern and change of soil organic carbon storage in China: 1960s1980s. Tellus B 55, 416-427.

Weiguo W, Yu Z, Haiqiu X, et al 2005. The relationship between characteristics of rice raw material and quality of rice noodle. Cereal \& Feed Industry (09):21-24.

Wittmann C, Aschan G, Pfanz H 2001. Leaf and twig photosynthesis of young beech (Fagus sylvatica) and aspen (Populus tremula) trees grown under different light regime. Basic and Applied Ecology, 2(2), pp.145-154.

Wu Q, Wang Y, Chen T, Zheng J, Sun Y, Chi, D 2020. Soil nitrogen regulation using clinoptilolite for grain filling and grain quality improvements in rice. Soil and Tillage Research, 199, p.104547. 
Xie H, Li J, Zhu P, Peng C, Wang J, He H, Zhang X 2014. Long-term manure amendments enhance neutral sugar accumulation in bulk soil and particulate organic matter in a mollisol. Soil Biology and Biochemistry 78, 45-53.

Yan X, Wang DJ, Zhang HL, Zhang G, Wei ZQ 2013. Organic amendments affect phosphorus sorption characteristics in a paddy soil. Agric. Ecosyst. Environ. 175, 47-53.

Yang Y, Lin G, Yu X, Wu Y, Xiong F 2020. Rice starch accumulation at different endosperm regions and physical properties under nitrogen treatment at panicle initiation stage. Int. J. Biol. Macromol

Yue S, Meng Q, Zhao R, Ye Y, Zhang F, Cui Z, et al. Change in nitrogen requirement with increasing grain yield for winter wheat. Agronomy Journal 2012;104(6):1687-93.

Zhang X, Davidson EA, Mauzerall DL, Searchinger TD, Dumas P, Shen YJN. Managing nitrogen for sustainable development. Nature 2015; 528(7580):51-9.

Zhang Y, Li C, Wang Y, Hu Y, Christie P, Zhang J, Li X 2016. Maize yield and soil fertility with combined use of compost and inorganic fertilizers on a calcareous soil on the North China Plain. Soil and Tillage Research 155, 85-94.

Zhao RF, Chen XP, Zhang FS, Zhang H, Schroder J, Römheld V 2006. Fertilization and nitrogen balance in a wheat-maize rotation system in North China. Agronomy Journal, 98(4), pp.938-945.

Zhou T, Zhou Q, Li E, Yuan L, Wang W, Zhang H, Gu J 2020. Effects of nitrogen fertilizer on structure and physicochemical properties of 'super'rice starch. Carbohydr. Polym. 116237.

Zhu T, Jackson DS, Wehling RL, Geera B 2008. Comparison of amylose determination methods and the development of a dual wavelength iodine binding technique. Cereal Chem. 85, 51-58.

\section{Table 3}


Table 3. Changes in grain yield, grain nutritive and appearance traits under the combined organic and inorganic fertilization.

\begin{tabular}{|c|c|c|c|c|c|c|c|c|}
\hline \multirow[t]{3}{*}{ Year } & Treatment & SDV & ER (\%) & Eve (\%) & PC (\%) & SC (\%) & $A C(\%)$ & $\begin{array}{l}\mathrm{GY}(\mathrm{kg} \\
\left.\mathrm{ha}^{-1}\right)\end{array}$ \\
\hline & $\mathrm{T}_{1}$ & $6.27 \mathrm{a}$ & 278 a & $92 a$ & $5.85 c$ & $71 \mathrm{~d}$ & $23.00 \mathrm{c}$ & $2899 d$ \\
\hline & $\mathrm{T}_{2}$ & $5.92 \mathrm{a}$ & $273 a$ & $92 \mathrm{a}$ & $6.55 b$ & $73 \mathrm{c}$ & $24.00 \mathrm{~b}$ & 4798 b \\
\hline \multirow[t]{4}{*}{2019} & $\mathrm{~T}_{3}$ & $5.52 \mathrm{a}$ & $285 \mathrm{a}$ & $92 \mathrm{a}$ & $6.41 b$ & $74 \mathrm{~b}$ & $24.00 \mathrm{~b}$ & $4236 \mathrm{c}$ \\
\hline & $\mathrm{T}_{4}$ & $5.44 \mathrm{a}$ & $279 a$ & $93 a$ & $7.20 \mathrm{a}$ & $76 a$ & $25.64 \mathrm{a}$ & $5412 \mathrm{a}$ \\
\hline & $\mathrm{T}_{5}$ & $5.53 \mathrm{a}$ & $290 a$ & $91 \mathrm{a}$ & $6.45 b$ & $74 \mathrm{~b}$ & $24.66 \mathrm{~b}$ & $4109 \mathrm{c}$ \\
\hline & $\mathrm{T}_{6}$ & $5.80 \mathrm{a}$ & $280 \mathrm{a}$ & $93 a$ & $7.35 \mathrm{a}$ & 76 a & $26.68 \mathrm{a}$ & $5428 \mathrm{a}$ \\
\hline \multirow[t]{3}{*}{ Averag } & & 5.75 & 280 & 92 & 6.64 & 74 & 24.66 & 4480 \\
\hline & $\mathrm{T}_{1}$ & $6.89 a$ & $265 \mathrm{a}$ & $93 a b$ & $5.72 \mathrm{c}$ & $70 \mathrm{c}$ & $21.00 \mathrm{~d}$ & $3278 d$ \\
\hline & $\mathrm{T}_{2}$ & $6.81 \mathrm{a}$ & $258 a b$ & $94 \mathrm{a}$ & $6.54 \mathrm{~b}$ & $71 \mathrm{c}$ & $23.00 \mathrm{c}$ & $5216 \mathrm{c}$ \\
\hline \multirow[t]{4}{*}{2020} & $\mathrm{~T}_{3}$ & $6.11 \mathrm{a}$ & $260 a b$ & $93 a b$ & $6.58 \mathrm{~b}$ & $75 b$ & $24.07 b$ & $6159 b$ \\
\hline & $\mathrm{T}_{4}$ & $6.34 \mathrm{a}$ & $252 a b$ & 94 a & $7.46 \mathrm{a}$ & $76 a$ & $26.11 \mathrm{a}$ & $6444 a$ \\
\hline & $\mathrm{T}_{5}$ & $6.84 a$ & $255 a b$ & $93 a b$ & $6.57 \mathrm{~b}$ & $75 b$ & $24.11 b$ & 6294 b \\
\hline & $\mathrm{T}_{6}$ & $6.66 \mathrm{a}$ & $258 a b$ & 94 a & $7.40 \mathrm{a}$ & 77 a & $26.18 \mathrm{a}$ & $6553 a$ \\
\hline \multicolumn{2}{|c|}{ Average } & 6.61 & 258 & 94 & 6.71 & 74 & 24.08 & 5657 \\
\hline \multicolumn{9}{|c|}{ ANOVA } \\
\hline \multicolumn{2}{|c|}{ Treatment $(\mathrm{T})$} & ns & ns & ns & * & ** & $\star \star$ & *夫 \\
\hline \multicolumn{2}{|c|}{ Year (Y) } & * & * & * & ns & ns & ns & ** \\
\hline \multicolumn{2}{|c|}{$\mathrm{T} \times \mathrm{Y}$} & ns & ns & ns & ns & ns & ns & Ns \\
\hline
\end{tabular}

Note: $\mathrm{T}_{1}-\mathrm{CF}, \mathrm{T}_{2}-100 \% \mathrm{CF}, \mathrm{T}_{3}-60 \% \mathrm{CM}+40 \% \mathrm{CF}, \mathrm{T}_{4}-30 \% \mathrm{CM}+70 \% \mathrm{CF}, \mathrm{T}_{5}-60 \% \mathrm{PM}+40 \% \mathrm{CF}, \mathrm{T}_{6}-30 \%$ $\mathrm{PM}+70 \% \mathrm{CF}$, SDV-starch dissolving value, ER-expansion rate, Eve-evenness, PC-protein content, SCstarch content, AC-amylose content, and GY-grain yield. Means sharing same letter within a category are non-significantly different from each other using Tukey HSD test at $\mathrm{P}<5 \%$. **, * $=$ significant at $5 \%$ and $1 \%$, respectively and $n s=$ non-significant.

\section{Figures}




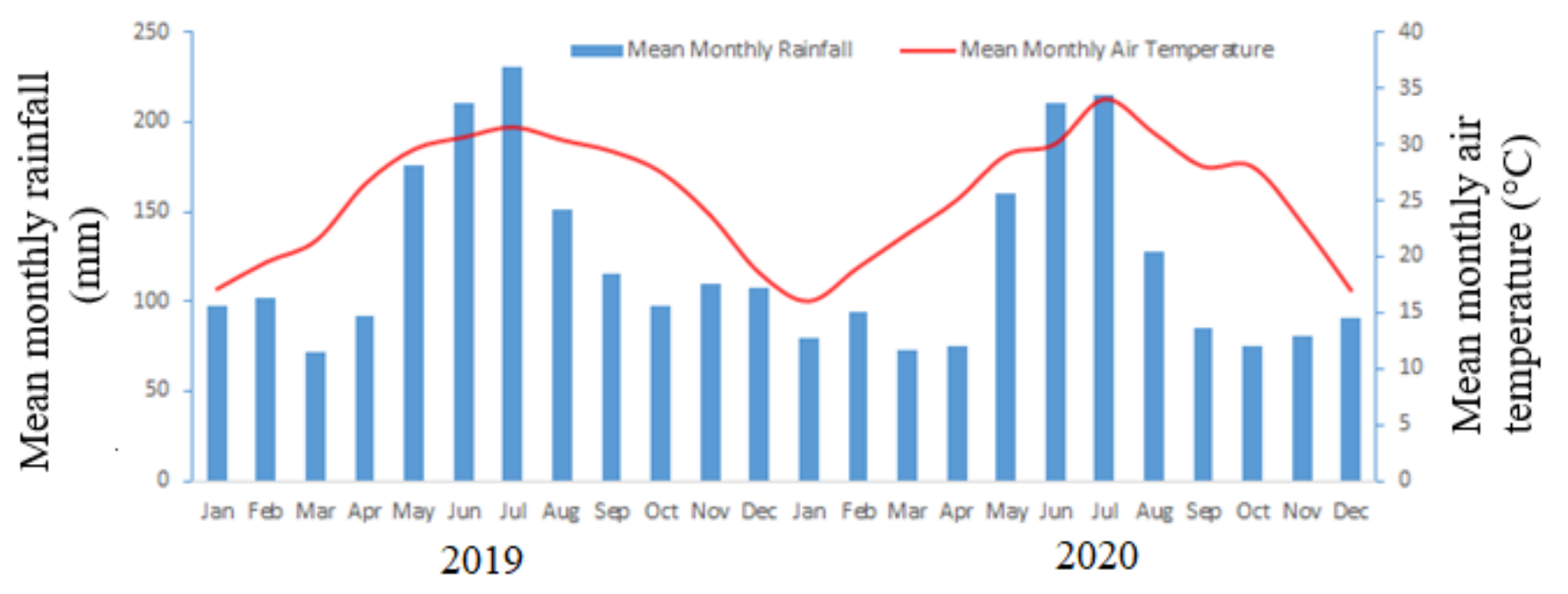

Figure 1

Mean monthly rainfall and air temperature during the experimental years.

$$
\text { Treatment }{ }^{* *} \quad \text { Year }^{* *} \quad T \times Y^{\text {ns }}
$$
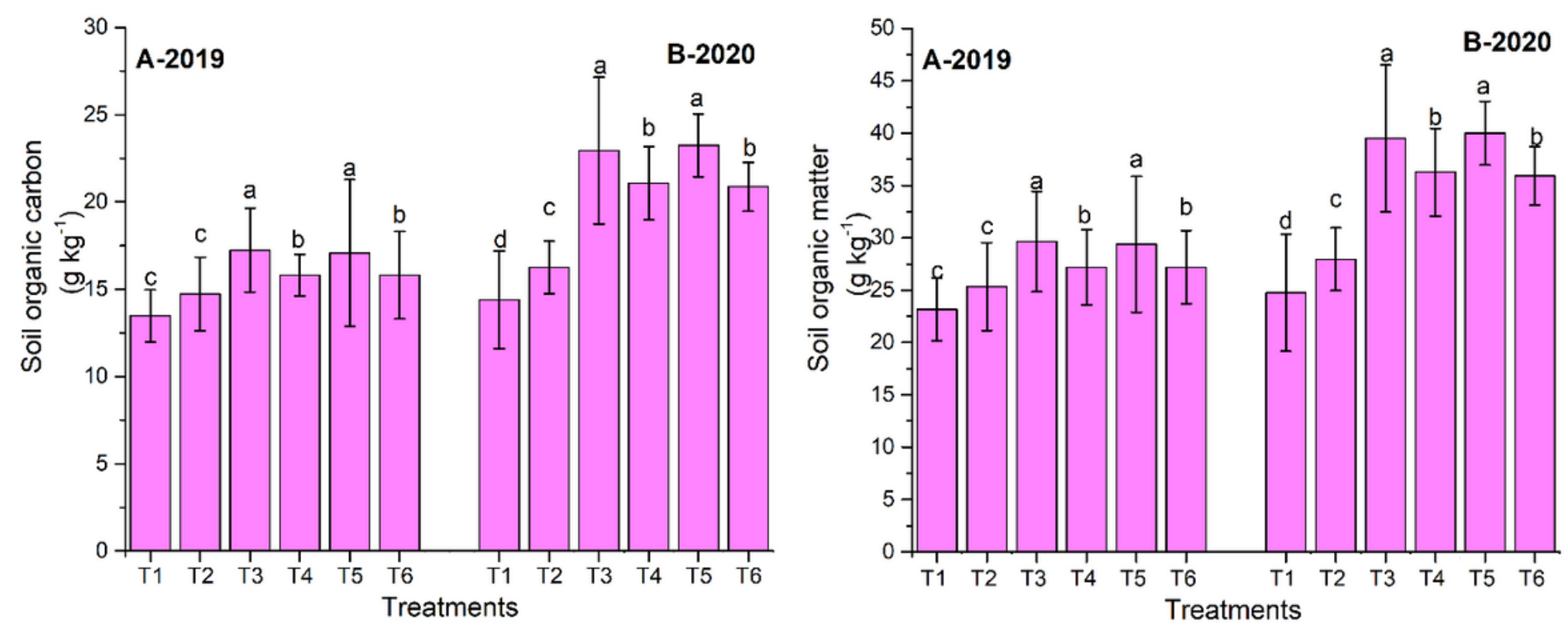

\section{Figure 2}

Changes in soil organic carbon ( $\mathrm{g} \mathrm{kg}-1$ ) and soil organic matter ( $\mathrm{g} \mathrm{kg}-1$ ) as influenced by combined organic and inorganic $\mathrm{N}$ fertilization. Means sharing the same letter within a category are nonsignificantly different from each other using the Tukey HSD test at $\mathrm{P}<5 \%$. ${ }^{\star *}=$ significant at $1 \%$, and ns= non-significant. For treatments combination please see Table 3. 
Treatment **

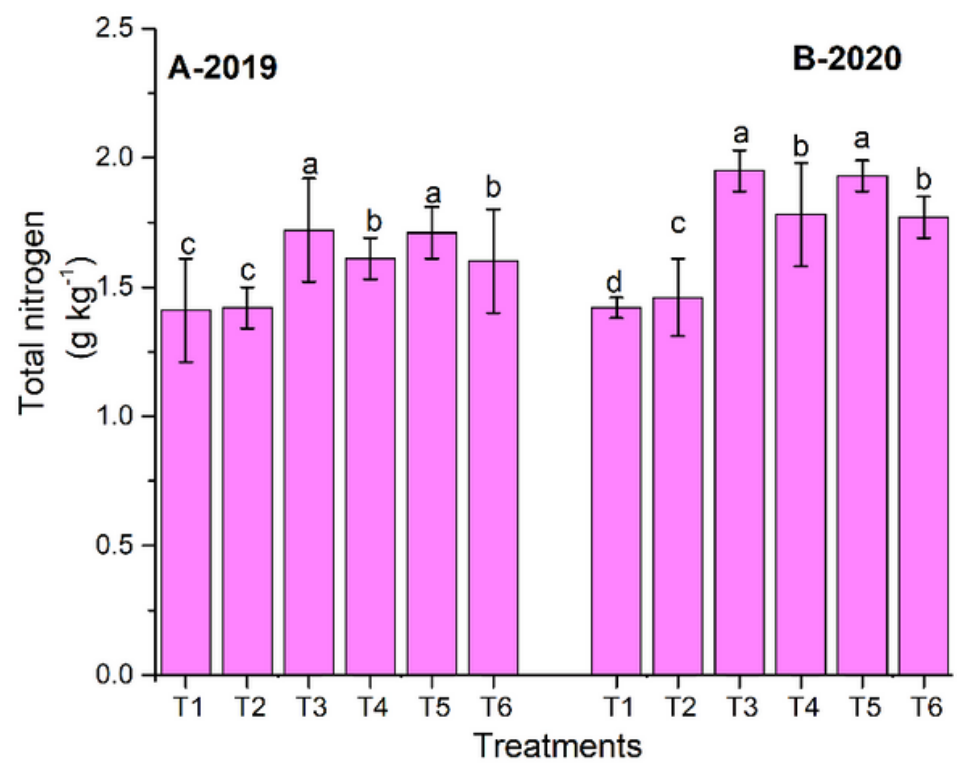

$T \times Y^{n s}$

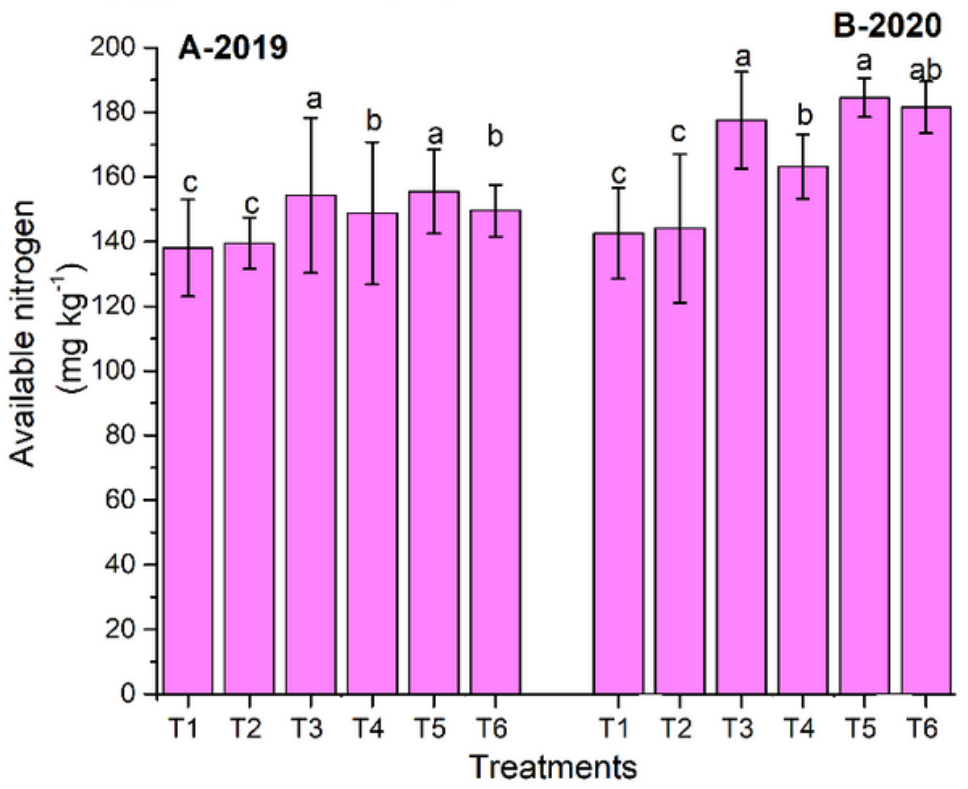

Figure 3

Changes in soil total nitrogen ( $\mathrm{g} \mathrm{kg}-1)$ and soil available nitrogen ( $\mathrm{mg} \mathrm{kg}-1)$ as influenced by combined organic and inorganic $\mathrm{N}$ fertilization. The mean comparison was made using Tukey tests for treatments and years and the lettering was on basis of Tukey HSD test at $5 \%$ using simple effect. $* *=$ significant at $1 \%$, respectively and ns= non-significant. For treatments combination please see Table 3.

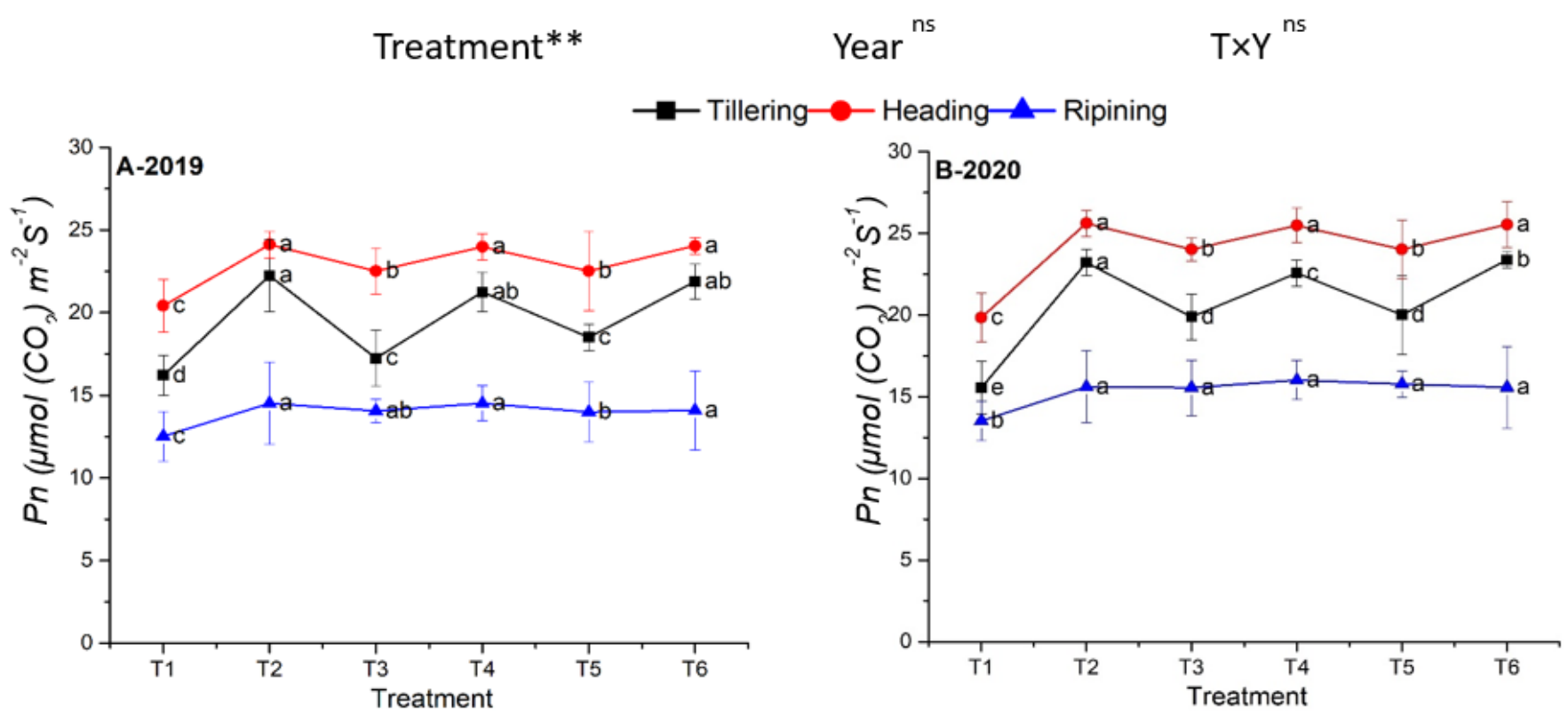

Figure 4

Changes in leaf net photosynthetic rate as influenced by combined organic and inorganic $\mathrm{N}$ fertilization. The mean comparison was made using Tukey tests for treatments and years and the lettering was on 
basis of Tukey HSD test at $5 \%$ using simple effect. ${ }^{*}, *=$ significant at $5 \%$ and $1 \%$, respectively and ns= non-significant. For treatments combination please see Table 3.

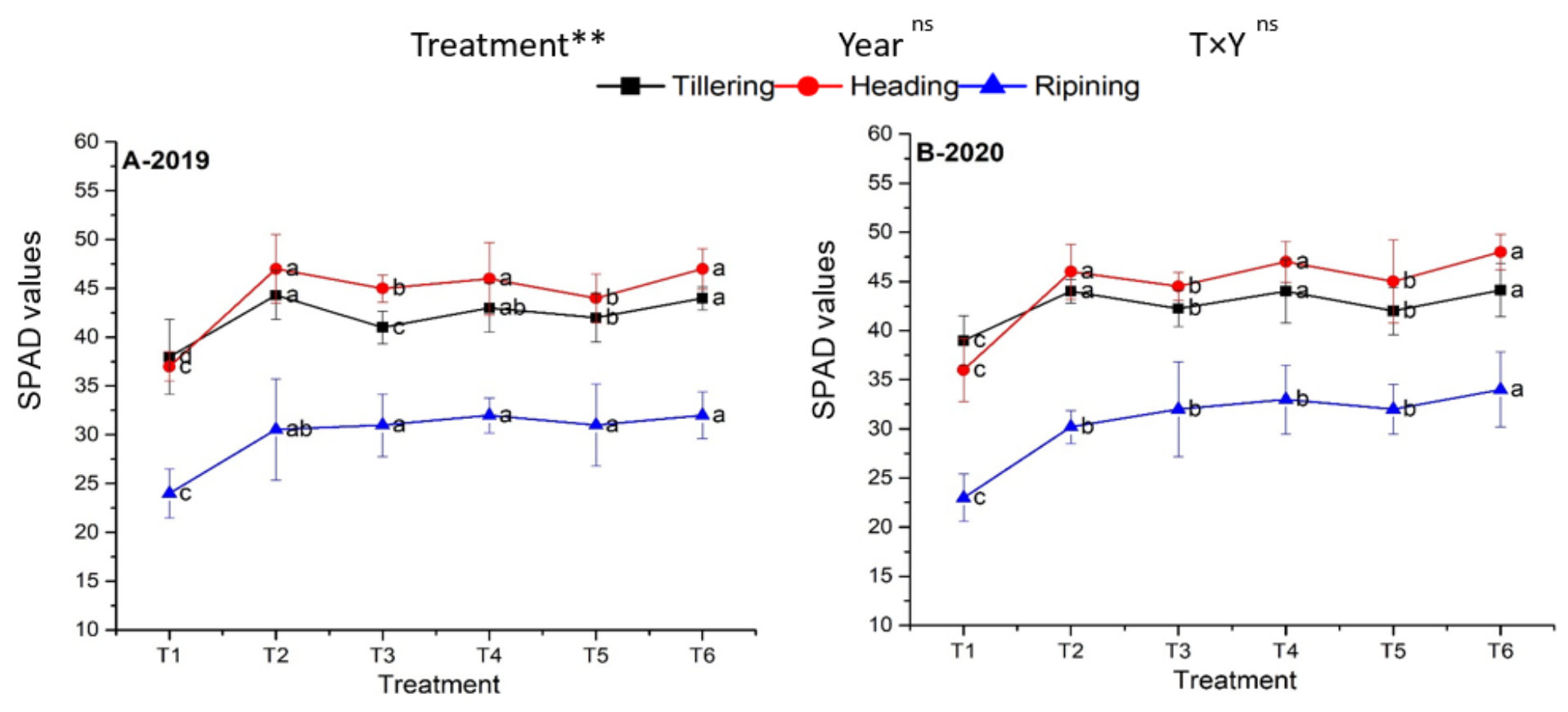

\section{Figure 5}

Changes in leaf SPAD values as influenced by combined organic and inorganic $\mathrm{N}$ fertilization. The mean comparison was made using Tukey tests for treatments and years and the lettering was on basis of Tukey HSD test at $5 \%$ using simple effect. ${ }^{*},{ }^{*}=$ significant at $5 \%$ and $1 \%$, respectively and $n s=$ nonsignificant. For treatments combination see please Table 3. 

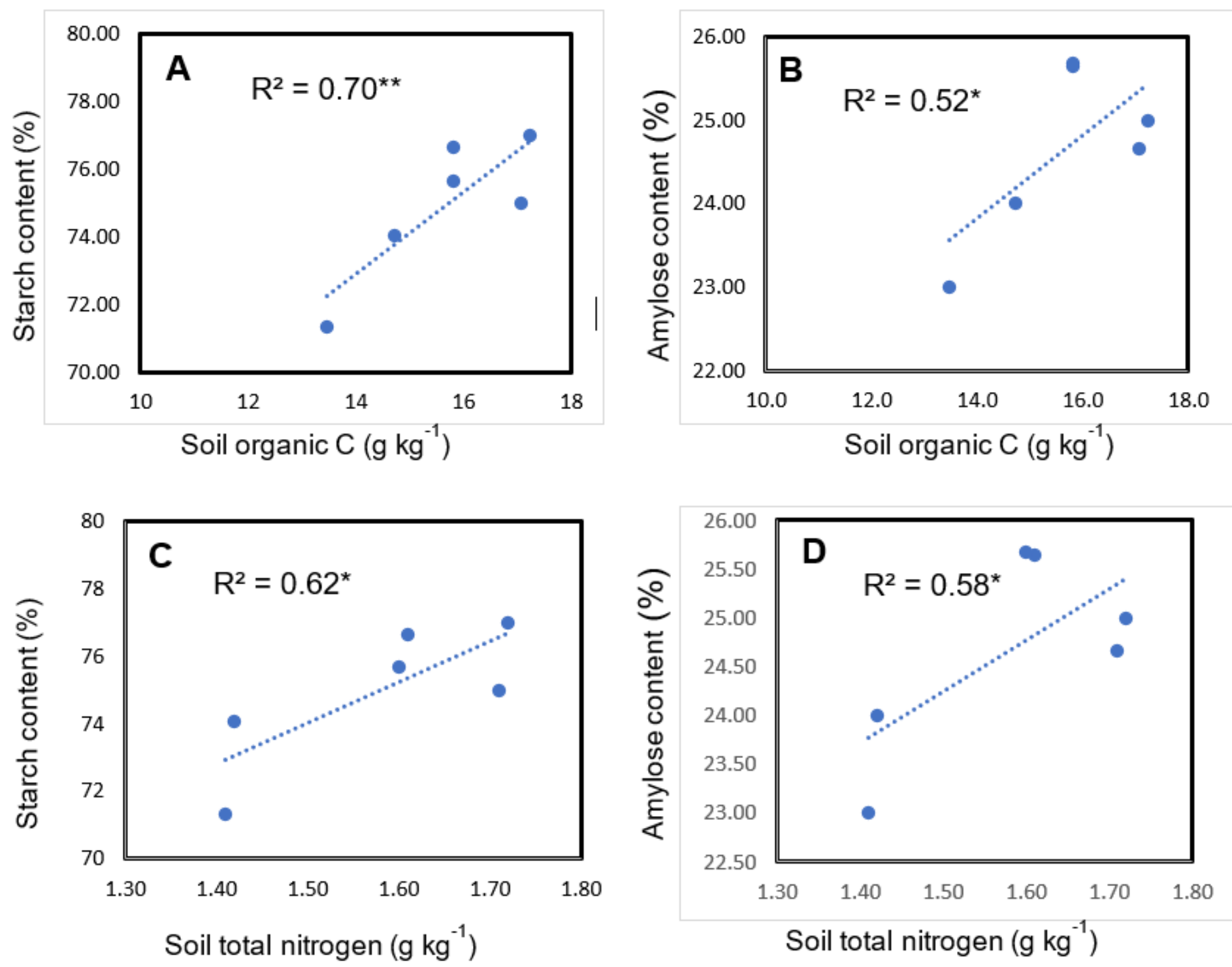

Figure 6

Linear regression of starch and amylose content with soil organic carbon and total nitrogen content. **, $*=$ significant at $5 \%$ and $1 \%$, respectively. $n=6$. 

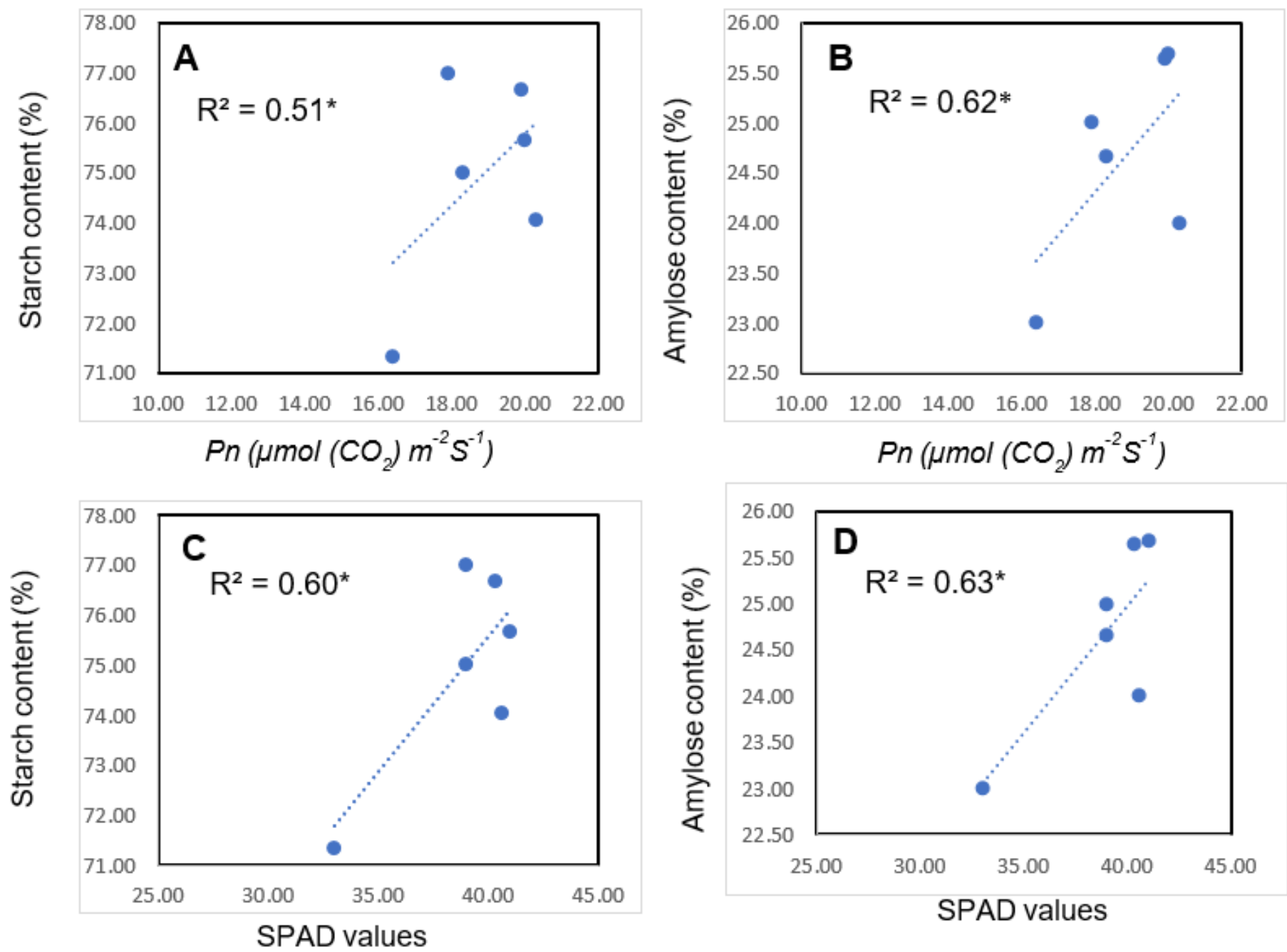

Figure 7

Linear regression of starch and amylose content with net photosynthetic rate $(\mathrm{Pn})$ and SPAD values * $=$ significant at $1 \% . n=6$. 